\title{
The Propagation of Rosa gallica 'Tuscany Superb' by Root Cuttings with the Use of IBA and Biostimulants
}

\author{
Marta Joanna MONDER*, Konrad WOLIŃSKI, Maciej NIEDZIELSKI \\ Polish Academy of Sciences Botanical Garden - Center for Biological Diversity Conservation in Powsin, Prawdziwka 2, 02-973 Warsaw, \\ Poland;m.monder@obpan.pl(*correspondingauthor);k.wolinski@obpan.pl;m.niedzielski@obpan.pl
}

\begin{abstract}
The research was aimed at studying the possibility of an alternative method of propagation the difficult-to-root Rosa gallica 'Tuscany Superb'. The root cuttings of three thickness were rooted using IBA preparations (Chryzotop green, Rhizopon AA 020XX) and biostimulants (Tytanit, Root Juice ${ }^{\mathrm{TM}}$ ). The shoots disappeared before the growth of the roots. At the first days of growth, the both shoots and roots elongated upright without polarity. The primordia of the first type of root/shoot buds were situated in cambium zone as the subtending traces of near the rays visible on the cross sections. Moreover, the second types of buds were located in pericycle tissues. The swellings suggested inherence buds were disappearing before rooting. The content of reducing and non-reducing carbohydrates was lower at the time of harvesting the rooted cuttings than before rooting. The thickness of the root cuttings had a significant importance for growth parameters and content of carbohydrates in rooted cuttings. The most useful root cuttings, those achieving the highest mean rooting percentage are thick $(76.8 \%)$ and medium (67.9\%) size. Preparations or biostimulants had a differential influence on rooting process and none of them unequivocally guaranteed an improvement in the rooting percentage of cuttings, parameters of growth or content of carbohydrates. The Rhizopon AA 020XX (90.0\%) in thick and Chryzotop green (87.5\%) in medium cuttings increased the rooting percentage significantly. Root Juice ${ }^{\mathrm{TM}}(0.1 \%, 0.2 \%)$ and Tytanit $(0.04 \%)$ were also enough positive activity in medium cuttings and can replace IBA preparations.
\end{abstract}

Keywords: carbohydrates; old roses; rhizogenesis; rhizomes; suckers; titanium

\section{Introduction}

The genus Rosa is one of the oldest and the most important ornamental plants. The biodiversity of the species, groups and cultivars of genus Rosa acts as the differentiation of the cultivation requirements and most sustainable methods of propagation. The technology of plant production should be quick, ecological, cheap and effective. The methods used for the propagation of roses are cuttings, suckers, layers, budding, grafting and micropropagation. In the case of old roses (groups of roses occurred before 1867) and varieties, the standard methods often fail or take a long time (Monder et al., 2014; Nasri et al., 2015). Propagation by root cuttings has the potential to be used for difficult-to-root taxa, including roses of different origins (Terpiński, 1984; Hartmann et al., 2011), e.g. Rosa nitida Will. The rhizome cuttings in roses may be treated the same as root cuttings, although the rhizomes are underground dorsiventral stems or branches growing horizontally under the surface of the soil (Terpiński, 1984).
The root cuttings require a new adventitious root and shoot system derived from adventitious buds, whereas the stem and one leaf-bud cuttings need only to form the root system. The formation of the roots or shoots is dependent on plant cell dedifferentiation that is pronounced by several factors or manipulations to provide the proper conditions for plant regeneration (Hartmann et al., 2011).

The plant growth regulators (PGRs) are standard rooting stimulators used for rooting. IBA (indole-3-butyric acid) is the most important one used to improve the quantity and quality of rose hardwood (Mahmoud, 1964; Ercişli et al., 2005; Kazankaya et al. 2005) and softwood cuttings (Nasri et al., 2015), also in increasing the carbohydrates (Monder and Pacholczak, 2018). The research demonstrated the positive effect on the early callusing, root initiation (Mahmoud, 1964) and number of young roots in roses (Nasri et al., 2015). However, in the case of difficult-to-root taxa, PGRs like IBA did not improve the rooting percentage (Hartmann et al., 2011; Monder and Pacholczak, 2018) and an increase in propagation efficiency may occur by changing the methods or conditions (Hartmann et al., 2011). 
692

Some current regulations in the European Union (15.07.1991, No. 91/41/EEC; 2009/128/WE, Official Journal the European Union) limit the use of chemicals and impose an obligation to use eco-friendly and integrated methods by all professional users of plant protection products. The use of natural products is recommended by the National Organic Program USDA and Organic Materials Review Institute (OMRI). This products may contain, for example, manure, animal or plant feedstock, living microbial cultures, algae, protein hydrolysate, humic and fulvic acids, processed food and industrial waste (Calvo et al., 2014).

Root Juice ${ }^{\mathrm{TM}}$ is a composition of algae extracts and humic acids (Table 1). The organic root stimulator boosts the existing root growth and encourages the development of new roots in cuttings and during replanting. Its use is recommended throughout the growing period to stimulate root growth and production (BioBizz Worldwide B.V. 2017). Root Juice ${ }^{\mathrm{TM}}$, used on the difficult-to-root gallica rose 'Duchesse d'Angoulême', had a positive effect on delaying the ageing processes in cuttings (Monder et al., 2014).

Titanium, in low concentrations, has an important positive effect on the growth and development of plant biomass or crop yields, through supporting the enzyme activities, nutrient uptake, chlorophyll biosynthesis and the intensity of photosynthesis (Dumon and Ernst, 1988; Lyu et al., 2017). Ti possesses probably a generally equalizing effect on the elements content $(\mathrm{Mg}, \mathrm{Fe}, \mathrm{Mn}, \mathrm{Zn})$ in the plant (Kuzel et al., 2007) and seemed to reduce the negative effects of heavy metal damage in wheat seedlings (Leskó et al., 2002). The critical tissue concentration that is potentially toxic but has not been clearly determined (Kuzel et al., 2007) and also titanium deficiency symptoms have not been described (Lyu et al., 2017). Most of the experiments with titanium refer to crops, vegetables and fruit plants, while reports regarding the rhizogenesis of cuttings with the use of preparations containing titanium are unknown. Titanium is applied to the soil or directly onto leaves or seeds (Lyu et al., 2017). Spraying of Sparaxis tricolor Ker-Gawl with Tytanit at a concentration of $0.04 \%$ increases the total yield of corms and the commercial yield, and improves the yield structure of the corms of the first quality. Higher concentrations $(0.08 \%)$ provoked unfavorable reaction on the commercial yield of corms (Marcinek and Hetman, 2008).

The research was aimed at verifying the possibility of effective propagation of difficult-to-root old rose 'Tuscany Superb' (Monder, 2016) by root/rhizome cuttings. The research included also biologically base according to anatomical structure of suckers and content of carbohydrates. The aim of research was to study the effect of thickness of used roots and treatment the IBA and ecofriendly preparations.

\section{Materials and Methods}

The research was conducted in Polish Academy of Sciences Botanical Garden Center for Biological Diversity Conservation in Powsin $\left(52.11^{\circ} \mathrm{N}, 21.10^{\circ} \mathrm{E}\right)$. The rhizomes of the shrub rose 'Tuscany Superb' (Gallica, T. Rivers and Son, before 1837), were collected from the National
Collection of Roses PAS CBDC in Powsin, on December 10-15th (2013 and 2014). From the rhizomes $9-10 \mathrm{~cm}$ long segments were trimmed and sorted into three sizes, according to their thickness: thick: $\varnothing 11-13 \mathrm{~mm}$, medium $\varnothing$ 8-10 $\mathrm{mm}$, thin $ø 6-7 \mathrm{~mm}$. The cuttings were protected from fungal diseases with Kaptan ${ }^{\oplus}$ 50WP (50\% captan) fungicide, tied into loose bundles (10-25 cuttings) and placed in boxes with a mixture of slightly moist peat and sand (1:2). The boxes were kept in a dark stockroom at a temperature of 3-5 ${ }^{\circ} \mathrm{C}$. Then, the cuttings were planted on 5-10 March, when the first buds were visible on the root cuttings, in plastic trays with an openwork bottom. The plastic trays were filled with peat (Karaska, Poland) and sand (Vistula river) mixture 1:1, pH 6.0-6.5. The cuttings were placed horizontally, in order to avoid polarity, at a spacing of $10 \mathrm{~cm}$ $x$ 5 $8 \mathrm{~cm}$ and then covered with $1.0-2.0 \mathrm{~cm}$ of the growing medium.

The cuttings were treated with preparations (Table 1), in 1-9 combination as described below:

1-Control (without treatment);

2-4-RootJuice ${ }^{\mathrm{TM}} 0.1,0.2$ and $0.4 \%$ : watering after planting ( $10 \mathrm{ml}$ per cutting), 14 and 28 days;

5-7-Tytanit $0.01,0.02$ and $0.04 \%$ : watering after planting ( $10 \mathrm{ml}$ per cutting), then spraying after 28 and 42 days;

8 -Chryzotop green, before rooting the $1 / 3$ half of bottom part of the cutting were dipped in rooting preparation and this part were placed horizontally in tray at the bottom;

9-Rhizopon AA $020 \mathrm{XX}$, used as above in Chryzotop green.

The plastic trays were kept in a container nursery. The cuttings were sprayed against fungal diseases every 10-14 days alternately with fungicides: Previcur Energy $840 \mathrm{SL}$ (propamocarb 47.28\%, fosetyl 27.65\%), Amistar 250 SC (azoxystrobin $250 \mathrm{~g} \cdot \mathrm{dm}^{-3}$ ), Score $250 \mathrm{SC}$ (difenoconazole $\left.250 \mathrm{~g} \cdot \mathrm{dm}^{-3}\right)$. The plants were fertilized with Ekolist $(0.01 \%)$ (Ekoplon S.A., Poland), twice: $1^{\text {st }}$ of June and $1^{\text {st }}$ of July.

The cuttings designed to anatomical observations were planted additionally and untreated any preparations. The observations were performed at the time of the appearance of the first buds on the root cuttings. The fragments of roots with buds were cut and stabilized in a solution of ethyl alcohol and glycerine (v:v 1:1). Then the segments were embedded in Technovit 7100. The samples were cut in sledge microtome pfm SLIDE 4003E (pfm medical AG, Germany) in slices with a thickness of 15-30 $\mu \mathrm{m}$ and observed in Olympus Vanox AHBT3 (Olympus America Inc., New York, USA) microscope. Additionally, the roots were cut in $100 \mu \mathrm{m}$ slices and observed in binocular. Slides were cross-dyed with a solution of safranin. The photos were taken with a digital camera Sony $\alpha 7$ connected with microscopy equipment.

The rooted root-cuttings were dug and estimated after 18 weeks, in the first days of August. The rooted cuttings were counted (\%) according to rooting degree in $2-5$ points. The rooting degree were specified in a valuation scale (1-5): 1 - no roots (only survived); 2 - a few, short roots $(1-10 \mathrm{~cm}$ ); 3 - 6-15 longer roots as $10 \mathrm{~cm} ; 4$ - 10-15 long, welldeveloped, branched roots; 5 - roots strong, well developed, forming a root ball. The root length from the origin of the root primordia of the longest root and the young shoot length from the base of the young shoot to the apical 
meristem of the longest shoot were measured. The number of shoots was counted as well. The total leaf area (all leaves on the shoot) was scanned with a leaf area meter (AM 300, ADC BioScientific Ltd., Hoddesdon, UK).

The content of carbohydrates was estimated in suckers in December, March and after rooting. Reducing (glucose) and non-reducing (saccharose) carbohydrates were determined by the Toczko and Grzelińska (2001) method. The measurements were made with spectrophotometer (GeneQuant 1300, GE) with the wave length of $520 \mathrm{~nm}$. The calibration curve was made for glucose. The content of sugars was calculated and the results are presented in $\mathrm{mg}$ of $\mathrm{C}_{6} \mathrm{H}_{12} \mathrm{O}_{6} \mathrm{~g}^{-1} \mathrm{FW}$.

The experimental design consisted of 9 treatments including 10 cuttings with four replicate ( 40 total). The total amount of cuttings was 1080, in three thicknesses of the roots. The experiment was based on a randomized block design. To compare the means, the percentage values have been transformed using the function $\operatorname{Arcsin}(\mathrm{x})^{1 / 2}$. The data were analysed with the ANOVA (two-way analysis of variance: thickness of cuttings, treatment; and three-way: thickness of cuttings, treatment, year) procedure followed by post-hoc Tukey's (growth parameters) and Duncan's (carbohydrates) tests, with Honest Significant Difference (HSD) at $\alpha=0.05$, using STATISTICA 10 (Statsoft Polska).

\section{Results and Discussion}

\section{The mode of roots and shoots}

The root cuttings of 'Tuscany Superb' in December had visible a few bumps, protuberances and swellings on the surface of the rhizomes suggesting the creation of adventitious buds (Fig. 1a,b). Adventitious roots mostly result from a plant injury (Hartmann et al., 2011), however in the case of the rose root cuttings in this experiment, the adventitious roots developed from adventitious buds over the whole length of the cut sucker and the bud formation was not connected with the location of the wound on the cuttings (Fig. 1a, b and d). The callus could disappear in the location of the wound after the cut, but without root formation.

The shoots disappeared before the roots (Fig. 1d) similar to Detarium (Ky-Dembele et al., 2010). In other plants, a well-developed root system has formed by the time the first shoots appear (Hartmann et al., 2011). The new root meristem can be more difficult to form than the adventitious shoot buds (Ky-Dembele et al., 2010). The position of cuttings with respect to gravity is not relevant in the case of 'Tuscany Superb' (Fig. 1a), similarly Rosa nitida Willd. (Terpiński, 1984). However, according to Terpiński (1984), Hartmann et al. (2011), the root cuttings of most species characterized by polarity, and the roots developed at the distal end (morphological bottom part) and shoots at the proximal (morphological top part) of the root what is correlated with the transportation of auxin.

The cross sections of rose root-cuttings presented typical anatomical structure (Fig. 2c) observed in another species (Bosela and Evers, 1997). The adventitious root/shoot buds in roses were situated near the rays and vascular system on all the tissue latitude (Fig. $2 \mathrm{a}, \mathrm{b}$ and d). The primordia of the first type of root/shoot buds were situated in cambium zone as the subtending traces of near the rays visible on the cross sections (Fig. 2a, b and d). Moreover, the second type of buds were located in pericycle tissues (Fig. 1c). The swellings suggested inherence buds were disappearing before rooting. It was shown that the adventitious root development follows the same pattern as the lateral root formation (Ermel et al., 2000). The development of the adventitious buds in roses such as Sassafras is connected with the subtending trace and wide pith rays (Fig. 2). Moreover, the Sassafras creates additional and reparative types of root buds revealing in pericycle (Bosela and Evers, 1997). The additional rose buds reveal as swellings and can be placed in the near cambial zone (Fig. 1).

\section{The quality and quantity of root cuttings 'Tuscany Superb'}

The high enough content of carbohydrates can be important for the success of the rhizogenesis process (Husen, 2008), wherein the soluble sugars are more important than starch in stem-rooting of olive (Denaxa et al., 2012). The level of carbohydrates in rose 'Tuscany Superb' didn't changed significantly in period DecemberMarch in root cuttings of rose 'Tuscany Superb' (Table 2). The carbohydrates reserves did not affected the rooting success but influenced root and shoot growth. The success of the propagation the aspen by root cuttings were influenced by many factors, e.g. the phenological period, cold storage, condition of the donor plants (Snedden et al., 2010).

The statistical analysis showed significant effects of the thickness of suckers and used preparations on rooting success (Table 3) and growth parameters (Tables 4-8). In this research the year of the experiment have an importance in rooting percentage only. The root cuttings of rose 'Tuscany Superb' rooted in a higher percentage in 2014 compared to 2015.

The rose 'Tuscany Superb' displays different rooting ability in respect to the thickness of cuttings. The highest rooting percentage in control, without using preparations, was obtained by thick root cuttings (76.3\%) as compared to medium $(30.0 \%)$ and thin $(32.8 \%)$ ones (Table 3). Perala (1978) showed, that the rooting percentage in aspen was not affected by root cuttings length $(100.0 \mathrm{~cm}$ and $12.5 \mathrm{~cm})$, but the growth was much better in the longer cuttings and

Table 1. The used preparations in the experiment

\begin{tabular}{ccc}
\hline Preparation & Contents & Producer \\
\hline Tytanit & Titanium (Ti) $0.8 \%\left(8.5{\left.\mathrm{~g} \cdot \mathrm{dm}^{-3}\right),}_{\text {Intermag }(\text { Poland })}\right.$ \\
RootJuice $^{\mathrm{TM}}$ & $\mathrm{Mg}(0.03 \%), \mathrm{Fe}(0.013 \%), \mathrm{Mn}(0.002 \%), \mathrm{Zn}(0.004 \%), \mathrm{B}(0.025 \%), \mathrm{Cu}(0.001 \%)$. & BioBizz Worldwide BV \\
Chryzotop Green & $0.25 \%$ indole-3-butyric acid (IBA) & Rhizopon BV (Netherlands) \\
Rhizopon AA 020 XX & $2.00 \%$ indole-3-butyric acid (IBA) & Rhizopon BV (Netherlands) \\
\hline
\end{tabular}




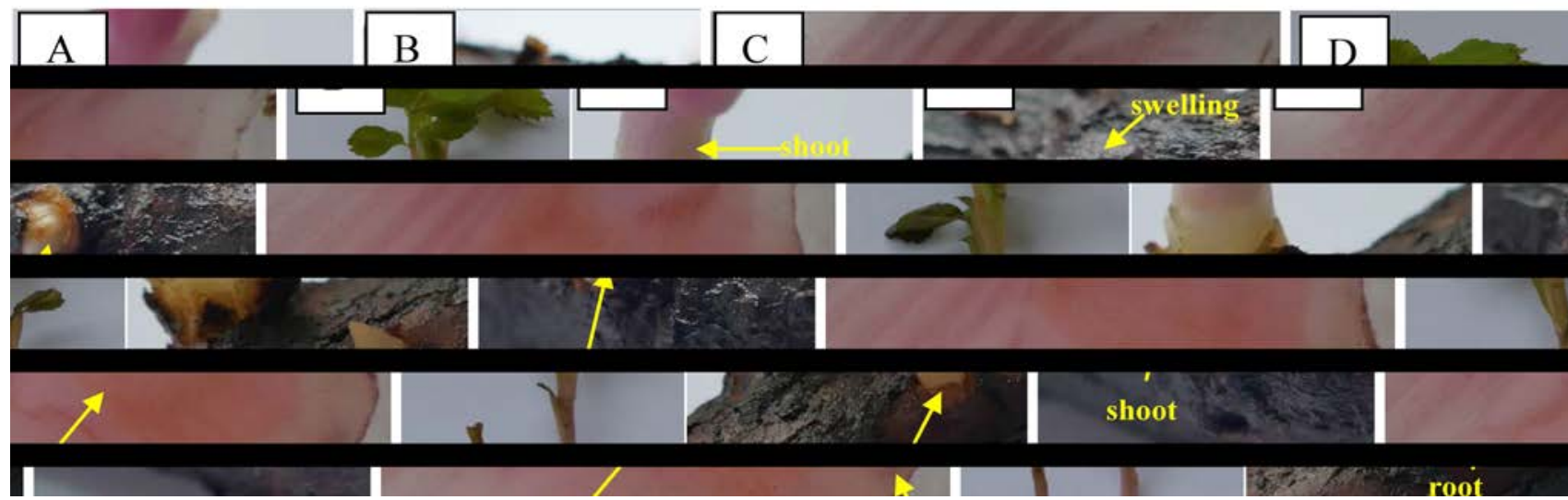

Fig. 1. The adventitious root buds growing without preserved polarity (A); additional bud growing from the swelling place (B, C); the shoots disappearing before the roots (D); in rose 'Tuscany Superb'

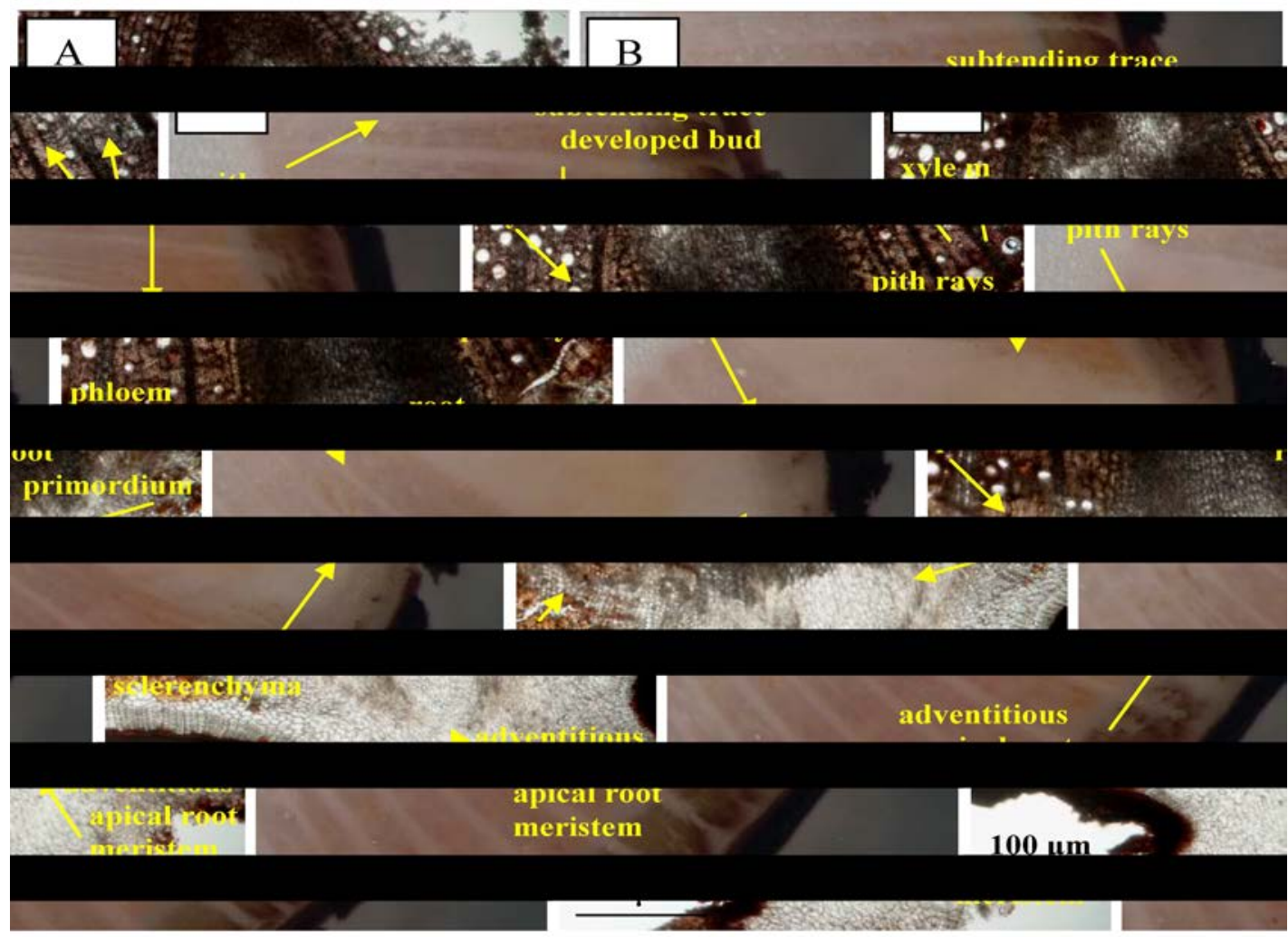

Fig. 2. The transversal sections of Rosa 'Tuscany Superb' root cuttings, showing adventitious root bud trace (A, B); the tissues of root cuttings in August (C); adventitious shoot bud trace (D). Primordium organizing in apical meristem showing adventitious shoot / root developing through the internal and well differentiated shoot bud trace (B)

those with a bigger diameter $(\varnothing>2.5 \mathrm{~cm})$ than in shorter and thinner cuttings $(\varnothing<1.6-2.5 \mathrm{~cm})$, because of the greater content of available carbohydrates (Schier and Zasada, 1973). This hypothesis has been confirmed in 'Tuscany Superb'. The level of the reducing and also non-reducing carbohydrates was the highest in thick root cuttings (Tables 4 and 5 ).

The preparations used for the improvement of the rooting percentages exhibited different activity. The most effective in the case of thick cuttings were IBA preparations Rhizopon AA $020 \mathrm{XX}(90.0 \%)$ and Chryzotop green $(85.0 \%)$. In the case of medium cuttings all the preparations increased the rooting percentage from $30.0 \%$ (Root Juice ${ }^{\mathrm{TM}}$ $0.4 \%$, Tytanit $0.01 \%$ ) to $57.5 \%$ (Rhizopon AA $020 \mathrm{XX}$ ) more (Table 3). This result can be connected with the content of the available sugars which was greater in the thick and long root cuttings (Schier and Zasada, 1973) similarly in this research (Tables 4 and 5), as evidenced by the positive reaction to the preparations containing nutrients. Root Juice ${ }^{\mathrm{TM}}$ increased the content of total carbohydrates in the leaves and stems of one bud stem cuttings of rooted rambler roses (Rosa beggeriana 'Polstjärnan' and $R$. helenae 'Semiplena'), but the rooting percentage was higher only in R. helenae 'Semiplena' (Monder and Pacholczak, 2018). 
In the case of thin root cuttings the higher concentrations of Tytanit $(0.02 \%, 0.04 \%)$ and IBA preparations decreased the rooting percentage comparing with the control (Table 3). The use of Rhizopon AA 020 XX in research of Monder (2016) caused unfavourable influence on rooting percentage of roses ('Harison's Yellow' $0 \%$, 'Poppius' $2 \%$ ) that may be generated by the high concentration of IBA (2.0\%). Ercişli et al. (2005) obtained a high percent of rooted hardwood cuttings Rosa dumalis Bechst. using the highest concentration of IBA (0.50\%), but this result was lower than the one using solution with the concentration of $0.35 \%$. These cuttings rooted $0-7.5 \%$ in the control, whereas when the basal part of the cutting was dipped in a water solution of IBA in a concentration of 0.15\%: 37.5-40.0\%, 0.35\%: 47.5-70.0\%, and 0.5\%: 40.0$62.5 \%$ rooting percentage, according to the substrate used.

The propagation by root cuttings seems to be a more effective method than by hardwood cuttings in some shrub difficult-to-root roses with ability to produce suckers. The hardwood cuttings of 'Tuscany Superb' did not root as well in greenhouses as in open fields irrespective of the use of the rooting stimulants containing IBA and NAA (Monder 2016).

After analyzing the experimental results it could be seen that any of the applied preparations guaranteed an improvement in the degree of rooting (Table 6) or the length of the roots (Table 7). The preparations have a differential action on the rooting system quality according to the thickness of the cuttings. Compared to rooted hardwood cuttings of old shrub roses ('Harison's Yellow' and 'Poppius') it could be seen that the root cuttings had a higher result in the degree of rooting (Monder, 2016). The application of all the preparations caused a decrease in the stated value in the thick cuttings comparing to the highest value in experiment in control (4.51). None of preparation didn't affect the rooting degree in medium cuttings comparing to the control. In the case of thin cuttings, the application of Tytanit $0.04 \%$ (3.20) and Chryzotop green (3.39) decreased the rooting degree comparing to the control (3.86) (Table 3). The method for evaluation of rooting degree was in Monder (2016) previous experiments in a similar valuation scale 1-5. It was showed, Root Juice ${ }^{\mathrm{TM}}$ did not influence the degree of rooting in one bud leaf stem cuttings of rambler roses (Monder, Pacholczak 2018). In Ercissli et al. (2005) research the quality of the rooted hardwood cuttings of $R$. dumalis Bechst. clearly improved after the use of IBA solutions, and a higher concentration resulted in a greater number and longer length of roots. However, the treatment with IBA showed no significant effects on the root length of the softwood cuttings of the dog rose (Rosa canina L.) (Hoşafçi et al., 2005).

The means of leaf area, number and length of shoots in the root cuttings of 'Tuscany Superb' were the highest in the thick size cuttings (Tables 8, 9 and 10). In the research $\mathrm{Ky}$ Dembele $e t$ al. (2010), the size of root segments significantly affected the regeneration ability of Detarium microcarpum Guill. \& Perr. The biggest cuttings (100 mm long, 21-40 $\mathrm{mm}$ diameter) had a higher sprouting efficiency and produced the largest, most vigorous sprouts. However, after eight weeks of observation no new roots were noticed regardless whether horizontal or vertical alignment of the root cuttings was applied (Ky-Dembele et al., 2010). The application of the preparations had different results for the means of number and length of shoots in respect to the thickness of the root cuttings. However, the preparation didn't affect the number shoots in three thickness of root cuttings and the length of shoots in thick and thin size (Tables 8 and 9). Compared with the hardwood cuttings, in the case of 'Harison's Yellow' the cuttings of this type had a longer length of shoots after the use of the rooting stimulants containing IBA (Monder, 2016).

In the case of leaf area in thick size cuttings, all the preparations increased the values of this parameter comparing with the control. The application of Root Juice $^{\mathrm{TM}}(0.2 \%, 0.4 \%)$ and Tytanit increased the means for medium and thin size cuttings. The using of Chryzotop green resulted also an increasing the leaf area in medium cuttings (Table 10).

Table 2. The content of reducing and non-reducing carbohydrates in root-cuttings of Rosa gallica 'Tuscany Superb'

\begin{tabular}{ccc}
\hline Treatment & \multicolumn{2}{c}{ Content of carbohydrates } \\
\cline { 2 - 3 } & Reducing $\left(\mathrm{mg} \mathrm{C}_{6} \mathrm{H}_{12} \mathrm{O}_{6} \cdot \mathrm{g} \mathrm{FW}^{-1}\right)$ & ${\text { Non-reducing }\left(\mathrm{mg} \mathrm{C}_{6} \mathrm{H}_{12} \mathrm{O}_{6} \cdot \mathrm{g} \mathrm{FW}^{-1}\right)}_{161.32 \mathrm{a}}^{136.11 \mathrm{a}}$ \\
\hline 15 December & $46.98 \mathrm{a}^{*}$ & $30.63 \mathrm{~b}$ \\
1 March & $45.35 \mathrm{a}$ & $11.72 \mathrm{c}$ \\
1 August (thick) & $40.02 \mathrm{~b}$ & $27.70 \mathrm{~b}$ \\
1 August (medium) & $25.97 \mathrm{~d}$ & $30.66 \mathrm{c}$ \\
\hline 1 August (thin) & & \\
\hline
\end{tabular}

${ }^{*}$ Note: values marked with the same letters in column do not differ significantly at $P \leq 0.05$ according to Duncan's HSD Test.

Table 3. The percentage (\%) of rooted root-cuttings of Rosa gallica'Tuscany Superb'

\begin{tabular}{|c|c|c|c|c|c|c|c|c|c|c|}
\hline \multirow{3}{*}{ Treatment } & \multicolumn{9}{|c|}{ Percentage of rooted root-cuttings in $\%$ / Thickness of root cuttings } & \multirow{3}{*}{ Mean } \\
\hline & \multicolumn{2}{|c|}{ Thick } & \multicolumn{2}{|c|}{ Medium } & \multicolumn{2}{|c|}{ Thin } & \multicolumn{3}{|c|}{ Mean } & \\
\hline & 2014 & 2015 & 2014 & 2015 & 2014 & 2015 & Thick & Medium & Thin & \\
\hline Control & 82.5 b-e ${ }^{*}$ & $70.0 \mathrm{f}-\mathrm{i}$ & $25.0 \mathrm{t}-\mathrm{z}$ & 35.0 rst & $35.0 \mathrm{rst}$ & $30.6 \mathrm{stu}$ & $76.3 \mathrm{EF}^{* *}$ & $30.0 \mathrm{~L}$ & $32.8 \mathrm{~L}$ & $46.3 \mathrm{C}^{\cdots}$ \\
\hline Root Juice $0.1 \%$ & $87.5 \mathrm{abc}$ & $75.0 \mathrm{~d}-\mathrm{g}$ & 82.5 b-e & $72.5 \mathrm{e}-\mathrm{h}$ & $70.0 \mathrm{f}-\mathrm{i}$ & $50.0 \mathrm{~m}-\mathrm{p}$ & $81.3 \mathrm{CD}$ & $77.5 \mathrm{E}$ & $60.0 \mathrm{I}$ & $72.9 \mathrm{~A}$ \\
\hline Root Juice $0.2 \%$ & $85.0 \mathrm{a}-\mathrm{d}$ & $72.5 \mathrm{e}-\mathrm{h}$ & $77.5 \mathrm{c}-\mathrm{f}$ & $67.5 \mathrm{~g}-j$ & $32.5 \mathrm{stu}$ & $25.0 \mathrm{t}-\mathrm{z}$ & $78.8 \mathrm{DE}$ & $72.5 \mathrm{FGH}$ & $28.8 \mathrm{LM}$ & $60.0 \mathrm{AB}$ \\
\hline Root Juice $0.4 \%$ & $60.0 \mathrm{i}-\mathrm{m}$ & $52.51-0$ & $65.0 \mathrm{~g}-\mathrm{k}$ & $55.0 \mathrm{k}-\mathrm{o}$ & $50.0 \mathrm{~m}-\mathrm{p}$ & 40.0 prs & $56.3 \mathrm{~J}$ & $60.0 \mathrm{I}$ & $45.0 \mathrm{~K}$ & $53.8 \mathrm{BC}$ \\
\hline Tytanit $0.01 \%$ & $72.5 \mathrm{e}-\mathrm{h}$ & $70.0 \mathrm{f}-\mathrm{i}$ & $65.0 \mathrm{~g}-\mathrm{k}$ & $55.0 \mathrm{k}-\mathrm{o}$ & $50.0 \mathrm{~m}-\mathrm{p}$ & 40.0 prs & $71.3 \mathrm{GH}$ & $60.0 \mathrm{I}$ & $45.0 \mathrm{~K}$ & $58.8 \mathrm{BC}$ \\
\hline Tytanit $0.02 \%$ & $75.0 \mathrm{~d}-\mathrm{g}$ & $65.0 \mathrm{~g}-\mathrm{k}$ & $77.5 \mathrm{c}-\mathrm{f}$ & $67.5 \mathrm{~g}-j$ & $30.0 \mathrm{stu}$ & $22.5 \mathrm{uwz}$ & $70.0 \mathrm{GH}$ & $72.5 \mathrm{FGH}$ & $26.3 \mathrm{M}$ & $56.2 \mathrm{BC}$ \\
\hline Tytanit $0.04 \%$ & $90.0 \mathrm{ab}$ & $75.0 \mathrm{~d}-\mathrm{g}$ & $90.0 \mathrm{ab}$ & $75.0 \mathrm{~d}-\mathrm{g}$ & $30.0 \mathrm{stu}$ & $15.0 \mathrm{z}$ & $82.5 \mathrm{CD}$ & $82.5 \mathrm{CD}$ & $22.5 \mathrm{~N}$ & $62.5 \mathrm{AB}$ \\
\hline Chryzotop Green (0.25\% IBA) & $92.5 \mathrm{a}$ & $77.5 c-f$ & $95.0 \mathrm{a}$ & $80.0 \mathrm{~b}-\mathrm{f}$ & $25.0 \mathrm{t}-\mathrm{z}$ & $17.5 \mathrm{wz}$ & $85.0 \mathrm{BC}$ & $87.5 \mathrm{AB}$ & $21.3 \mathrm{~N}$ & $64.6 \mathrm{AB}$ \\
\hline Rhizopon AA $020 \mathrm{XX}(2.00 \%$ IBA $)$ & $95.0 \mathrm{a}$ & $85.0 \mathrm{a}-\mathrm{d}$ & $72.5 \mathrm{e}-\mathrm{h}$ & $65.0 \mathrm{~g}-\mathrm{k}$ & $25.0 \mathrm{t}-\mathrm{z}$ & $17.5 \mathrm{wz}$ & $90.0 \mathrm{~A}$ & $68.8 \mathrm{H}$ & $21.3 \mathrm{~N}$ & $60.0 \mathrm{AB}$ \\
\hline Mean & $82.2 \mathrm{~A}^{\cdots}$ & $71.4 \mathrm{~B}$ & $72.2 \mathrm{~A}$ & $63.6 \mathrm{~B}$ & $38.6 \mathrm{~A}$ & $28.7 \mathrm{~B}$ & $76.8 \mathrm{~A}$ & $67.9 \mathrm{~A}$ & $33.6 \mathrm{~B}$ & \\
\hline
\end{tabular}

Note: different small letters indicate significant interactions between treatment, thickness and year of cuttings, according to Tukey's HSD test $(P \leq 0.05)$;

${ }^{* *}$ Note: different capital letters indicate significant interactions between treatment and thickness of cuttings, according to Tukey's HSD test $(P \leq 0.05)$;

${ }^{* * *}$ Note: mean values marked with the same capital letters in column or row do not differ significantly at $P \leq 0.05$ according to Tukey's HSD test 
Table 4. The content of reducing carbohydrates in root-cuttings of Rosa gallica 'Tuscany Superb'

\begin{tabular}{|c|c|c|c|c|}
\hline \multirow{3}{*}{ Treatment } & \multicolumn{3}{|c|}{ Content of reducing carbohydrates $\left(\mathrm{mg} \mathrm{C}_{6} \mathrm{H}_{12} \mathrm{O}_{6} \cdot \mathrm{g} \mathrm{FW}^{-1}\right)$} & \multirow{3}{*}{ Mean } \\
\hline & \multicolumn{3}{|c|}{ Thickness of root cuttings } & \\
\hline & Thick & Medium & Thin & \\
\hline Control & $40.03 \mathrm{~d}^{*}$ & $25.97 \mathrm{k}$ & $30.66 \mathrm{i}$ & $32.22 \mathrm{~A}^{* *}$ \\
\hline Root Juice $0.1 \%$ & $36.79 \mathrm{f}$ & $35.44 \mathrm{~g}$ & $15.10 \mathrm{p}$ & $29.11 \mathrm{C}$ \\
\hline Root Juice $0.2 \%$ & $33.41 \mathrm{~h}$ & $20.79 n$ & $23.07 \mathrm{~m}$ & $25.76 \mathrm{E}$ \\
\hline Root Juice $0.4 \%$ & $38.60 \mathrm{e}$ & $20.45 n$ & $31.96 \mathrm{i}$ & $30.34 \mathrm{~B}$ \\
\hline Tytanit $0.01 \%$ & $34.27 \mathrm{gh}$ & $28.72 \mathrm{j}$ & 24.511 & $29.17 \mathrm{C}$ \\
\hline Tytanit $0.02 \%$ & $45.35 \mathrm{~b}$ & $19.57 \mathrm{n}$ & $30.84 \mathrm{i}$ & $31.92 \mathrm{~A}$ \\
\hline Tytanit $0.04 \%$ & $40.92 \mathrm{~d}$ & $34.41 \mathrm{gh}$ & $9.41 \mathrm{r}$ & $28.25 \mathrm{D}$ \\
\hline Chryzotop Green (0.25\% IBA) & $46.94 \mathrm{a}$ & $10.40 \mathrm{r}$ & $3.97 \mathrm{~s}$ & $20.44 \mathrm{G}$ \\
\hline Rhizopon AA 020 XX (2.00\% IBA) & $43.92 \mathrm{c}$ & 17.77 o & $3.42 \mathrm{~s}$ & $21.70 \mathrm{~F}$ \\
\hline Mean & $40.03 \mathrm{~A}^{* *}$ & $23.72 \mathrm{~B}$ & $19.22 \mathrm{C}$ & \\
\hline
\end{tabular}

Note: different letters indicate significant interactions between treatment and thickness of cuttings, according to Duncan's HSD test $(P \leq 0.05$; two-way ANOVA);

"Note: mean values marked with the same capital letters in column or row do not differ significantly at $P \leq 0.05$ according to Duncan's HSD test

Table 5. The content of non-reducing carbohydrates in root-cuttings of Rosa gallica 'Tuscany Superb’

\begin{tabular}{|c|c|c|c|c|}
\hline \multirow{3}{*}{ Treatment } & \multicolumn{3}{|c|}{ Content of non-reducing carbohydrates $\left(\mathrm{mg} \mathrm{C}_{6} \mathrm{H}_{12} \mathrm{O}_{6} \cdot \mathrm{g} \mathrm{FW}^{-1}\right)$} & \multirow{3}{*}{ Mean } \\
\hline & \multicolumn{3}{|c|}{ Thickness of root cuttings } & \\
\hline & Thick & Medium & Thin & \\
\hline Control & $30.63 \mathrm{f}^{*}$ & $11.71 \mathrm{p}$ & $27.70 \mathrm{~h}$ & $23.35 \mathrm{C}^{*}$ \\
\hline Root Juice $0.1 \%$ & $30.75 \mathrm{f}$ & $20.72 j$ & $9.98 \mathrm{~s}$ & $20.48 \mathrm{E}$ \\
\hline Root Juice $0.2 \%$ & $16.57 \mathrm{k}$ & $6.79 \mathrm{u}$ & 15.441 & $12.93 \mathrm{G}$ \\
\hline Root Juice $0.4 \%$ & $11.97 \mathrm{o}$ & $7.33 \mathrm{t}$ & $39.92 \mathrm{~d}$ & $19.74 \mathrm{~F}$ \\
\hline Tytanit $0.01 \%$ & $10.56 \mathrm{r}$ & $21.17 j$ & $30.21 \mathrm{~g}$ & $20.65 \mathrm{E}$ \\
\hline Tytanit $0.02 \%$ & $21.23 \mathrm{i}$ & $11.02 \mathrm{p}$ & $33.96 \mathrm{e}$ & $22.07 \mathrm{D}$ \\
\hline Tytanit $0.04 \%$ & $68.55 \mathrm{~b}$ & $47.03 \mathrm{c}$ & $9.97 \mathrm{~s}$ & $41.85 \mathrm{~A}$ \\
\hline Chryzotop Green (0.25\% IBA) & $72.57 \mathrm{a}$ & 15.331 & $14.87 \mathrm{~m}$ & $34.26 \mathrm{~B}$ \\
\hline Rhizopon AA 020 XX (2.00\% IBA) & $12.87 \mathrm{n}$ & $5.65 \mathrm{w}$ & 15.591 & $11.37 \mathrm{H}$ \\
\hline Mean & $30.63 \mathrm{~A}^{* *}$ & $16.31 \mathrm{C}$ & $21.96 \mathrm{~B}$ & \\
\hline
\end{tabular}

${ }^{7}$ Note: different letters indicate significant interactions between treatment and thickness of cuttings, according to Duncan's HSD test $(P \leq 0.05$; two-way ANOVA); ${ }^{*}$ Note: mean values marked with the same capital letters in column or row do not differ significantly at $P \leq 0.05$ according to Duncan's HSD test

Table 6. The means of rooting degree of rooted root-cuttings (valuation scale 2-5) of Rosa gallica 'Tuscany Superb' in the 2014-2015 years. The rooting degree were specified in valuation scale (1-5): 1 - no roots; 2 - a few, short roots $(1-10 \mathrm{~cm}) ; 3-6-15$ longer roots as $10 \mathrm{~cm} ; 4-10-15$ long, well-developed, branched roots; 5 - roots long, strong, well developed, branched, forming a root ball

\begin{tabular}{|c|c|c|c|c|}
\hline \multirow{3}{*}{ Treatment } & \multicolumn{3}{|c|}{ Rooting degree in valuation scale $1-5$} & \multirow{3}{*}{ Mean } \\
\hline & \multicolumn{3}{|c|}{ Thickness of root cuttings } & \\
\hline & Thick & Medium & Thin & \\
\hline Control & $4.51 \mathrm{a}^{*}$ & $4.06 \mathrm{~b}-\mathrm{f}$ & $3.86 \mathrm{~d}-\mathrm{g}$ & $4.15 \mathrm{~A}^{* *}$ \\
\hline Root Juice $0.1 \%$ & 3.90 def & $3.98 c-f$ & $3.73 \mathrm{~d}-\mathrm{h}$ & $3.88 \mathrm{~B}-\mathrm{D}$ \\
\hline Root Juice $0.2 \%$ & $3.61 \mathrm{~d}-\mathrm{h}$ & $3.86 \mathrm{~d}-\mathrm{g}$ & $3.67 \mathrm{~d}-\mathrm{h}$ & $3.72 \mathrm{D}$ \\
\hline Root Juice $0.4 \%$ & $3.88 \mathrm{def}$ & $4.05 \mathrm{~b}-\mathrm{f}$ & $3.72 \mathrm{~d}-\mathrm{h}$ & $3.90 \mathrm{~B}-\mathrm{D}$ \\
\hline Tytanit $0.01 \%$ & $3.95 \mathrm{def}$ & $4.38 \mathrm{abc}$ & $3.62 \mathrm{~d}-\mathrm{h}$ & $4.01 \mathrm{AB}$ \\
\hline Tytanit $0.02 \%$ & $3.68 \mathrm{~d}-\mathrm{h}$ & $3.90 \mathrm{~d}-\mathrm{f}$ & $3.85 \mathrm{efg}$ & $3.80 \mathrm{CD}$ \\
\hline Tytanit $0.04 \%$ & $3.74 \mathrm{~d}-\mathrm{h}$ & $4.30 \mathrm{a}-\mathrm{d}$ & $3.20 \mathrm{i}$ & $3.95 \mathrm{~A}-\mathrm{C}$ \\
\hline Chryzotop Green (0.25\% IBA) & $3.87 \mathrm{~d}-\mathrm{g}$ & $4.25 \mathrm{a}-\mathrm{e}$ & $3.39 \mathrm{hi}$ & $4.00 \mathrm{~A}-\mathrm{C}$ \\
\hline Rhizopon AA $020 \mathrm{XX}(2.00 \%$ IBA $)$ & $4.00 \mathrm{c}-\mathrm{f}$ & $4.43 \mathrm{ab}$ & $3.43 \mathrm{ghi}$ & $4.12 \mathrm{~A}$ \\
\hline Mean & $3.87 \mathrm{~B}^{* *}$ & $4.14 \mathrm{~A}$ & $3.66 \mathrm{C}$ & \\
\hline
\end{tabular}

${ }^{*}$ Note: different letters indicate significant interactions between treatment and thickness of cuttings, according to Tukey's HSD test $(P \leq 0.05$; two-way ANOVA);

${ }^{* *}$ Note: mean values marked with the same capital letters in column or row do not differ significantly at $P \leq 0.05$ according to Tukey's HSD test 
Table 7. The means of the length of roots of rooted root-cuttings of Rosa gallica 'Tuscany Superb'

\begin{tabular}{|c|c|c|c|c|}
\hline \multirow{2}{*}{ Treatment } & \multicolumn{3}{|c|}{ Length of roots in $\mathrm{cm} /$ Thickness of root cuttings } & \multirow{2}{*}{ Mean } \\
\hline & Thick & Medium & Thin & \\
\hline Control & $9.03 \mathrm{e}-\mathrm{i}^{1}$ & $13.25 \mathrm{a}$ & $11.40 \mathrm{a}-\mathrm{d}$ & $11.12 \mathrm{AB}^{2}$ \\
\hline Root Juice $0.1 \%$ & $9.77 \mathrm{c}-\mathrm{i}$ & $13.00 \mathrm{ab}$ & $10.47 \mathrm{c}-\mathrm{f}$ & $11.13 \mathrm{ABC}$ \\
\hline Root Juice $0.2 \%$ & $8.52 \mathrm{f}-\mathrm{j}$ & $11.47 \mathrm{a}-\mathrm{c}$ & $13.13 \mathrm{a}$ & $10.44 \mathrm{BCD}$ \\
\hline Root Juice $0.4 \%$ & $8.31 \mathrm{~g}-\mathrm{j}$ & $12.86 \mathrm{ab}$ & $10.55 \mathrm{c}-\mathrm{f}$ & $10.62 \mathrm{BCD}$ \\
\hline Tytanit $0.01 \%$ & $9.69 \mathrm{c}-\mathrm{i}$ & $10.43 \mathrm{c}-\mathrm{g}$ & $9.32 \mathrm{~d}-\mathrm{i}$ & $9.84 \mathrm{DE}$ \\
\hline Tytanit $0.02 \%$ & $8.16 \mathrm{~h}-\mathrm{j}$ & $10.53 \mathrm{c}-\mathrm{f}$ & $8.47 \mathrm{f}-\mathrm{j}$ & $9.25 \mathrm{EF}$ \\
\hline Tytanit $0.04 \%$ & $7.82 \mathrm{ij}$ & $12.62 \mathrm{ab}$ & $10.13 \mathrm{c}-\mathrm{i}$ & $10.22 \mathrm{CD}$ \\
\hline Chryzotop Green $(0.25 \%$ IBA $)$ & $8.61 f_{-j}$ & $9.51 \mathrm{c}-\mathrm{i}$ & $6.55 \mathrm{j}$ & $8.82 \mathrm{~F}$ \\
\hline Rhizopon AA 020 XX (2.00\% IBA) & $11.00 \mathrm{~b}-\mathrm{e}$ & $13.36 \mathrm{a}$ & $7.70 \mathrm{ij}$ & $11.63 \mathrm{~A}$ \\
\hline Mean & $9.05 C^{2}$ & $11.78 \mathrm{~A}$ & $10.08 \mathrm{~B}$ & \\
\hline
\end{tabular}

"Note: different letters indicate significant interactions between treatment and thickness of cuttings, according to Tukey's HSD test (P $\leq 0.05$; two-way ANOVA);

${ }^{* *}$ Note: mean values marked with the same capital letters in column or row do not differ significantly at $P \leq 0.05$ according to Tukey's HSD test

Table 8. The means of the number of shoots of root-cuttings of Rosa gallica 'Tuscany Superb'

\begin{tabular}{|c|c|c|c|c|}
\hline \multirow{2}{*}{ Treatment } & \multicolumn{3}{|c|}{ Number of shoots of root-cuttings / Thickness of root cuttings } & \multirow{2}{*}{ Mean } \\
\hline & Thick & Medium & Thin & \\
\hline Control & $1.22 \mathrm{a}-\mathrm{c}^{-}$ & $1.19 \mathrm{a}-\mathrm{c}$ & $1.09 \mathrm{c}$ & $1.17 \mathrm{~A}-\mathrm{D}$ \\
\hline Root Juice $0.1 \%$ & $1.22 \mathrm{a}-\mathrm{c}$ & $1.10 \mathrm{bc}$ & $1.23 \mathrm{a}-\mathrm{c}$ & $1.19 \mathrm{~A}-\mathrm{C}$ \\
\hline Root Juice $0.2 \%$ & $1.19 \mathrm{a}-\mathrm{c}$ & $1.09 \mathrm{c}$ & $1.09 \mathrm{c}$ & $1.13 \mathrm{~B}-\mathrm{D}$ \\
\hline Root Juice $0.4 \%$ & $1.29 \mathrm{ab}$ & $1.28 \mathrm{ab}$ & $1.09 \mathrm{c}$ & $1.23 \mathrm{~A}$ \\
\hline Tytanit $0.01 \%$ & $1.33 \mathrm{a}$ & $1.15 \mathrm{bc}$ & $1.10 \mathrm{c}$ & $1.21 \mathrm{AB}$ \\
\hline Tytanit $0.02 \%$ & $1.09 \mathrm{c}$ & $1.09 \mathrm{c}$ & $1.09 \mathrm{c}$ & $1.09 \mathrm{D}$ \\
\hline Tytanit $0.04 \%$ & $1.16 \mathrm{a}-\mathrm{c}$ & $1.09 \mathrm{c}$ & $1.10 \mathrm{c}$ & $1.13 \mathrm{CD}$ \\
\hline Chryzotop Green (0.25\% IBA) & $1.22 \mathrm{a}-\mathrm{c}$ & $1.10 \mathrm{c}$ & $1.09 \mathrm{c}$ & 1.15 A-D \\
\hline Rhizopon AA 020 XX (2.00\% IBA) & $1.28 \mathrm{ab}$ & $1.14 \mathrm{bc}$ & $1.10 \mathrm{c}$ & $1.21 \mathrm{AB}$ \\
\hline Mean & $1.22 \mathrm{~A}^{* *}$ & $1.13 \mathrm{~B}$ & $1.12 \mathrm{~B}$ & \\
\hline
\end{tabular}

Note: different letters indicate significant interactions between treatment and thickness of cuttings, according to Tukey's HSD test $(P \leq 0.05$; two-way ANOVA)

"Note: mean values marked with the same capital letters in column or row do not differ significantly at $P \leq 0.05$ according to Tukey's HSD test

Table 9. The means of length of shoots of rooted root-cuttings of Rosa gallica 'Tuscany Superb'

\begin{tabular}{|c|c|c|c|c|}
\hline \multirow{2}{*}{ Treatment } & \multicolumn{3}{|c|}{ Length of shoots in $\mathrm{cm} /$ Thickness of root cuttings } & \multirow{2}{*}{ Mean } \\
\hline & Thick & Medium & Thin & \\
\hline Control & $17.88 \mathrm{a}-\mathrm{d}^{*}$ & $15.94 \mathrm{~b}-\mathrm{g}$ & $12.43 \mathrm{~g}-j$ & $15.50 \mathrm{~B}^{\prime \prime}$ \\
\hline Root Juice $0.1 \%$ & $19.97 \mathrm{a}$ & $12.10 \mathrm{~h}-\mathrm{j}$ & $15.36 \mathrm{~b}-\mathrm{i}$ & $15.93 \mathrm{~B}$ \\
\hline Root Juice $0.2 \%$ & $16.39 \mathrm{a}-\mathrm{f}$ & $14.57 \mathrm{c}-\mathrm{j}$ & $13.55 \mathrm{f}-\mathrm{j}$ & $15.21 \mathrm{~B}$ \\
\hline Root Juice $0.4 \%$ & $17.81 \mathrm{a}-\mathrm{d}$ & $15.11 \mathrm{~b}-\mathrm{j}$ & $14.01 \mathrm{e}-\mathrm{j}$ & $15.76 \mathrm{~B}$ \\
\hline Tytanit $0.01 \%$ & $18.54 \mathrm{ab}$ & $15.68 \mathrm{~b}-\mathrm{h}$ & $14.89 \mathrm{~b}-\mathrm{j}$ & $16.70 \mathrm{AB}$ \\
\hline Tytanit $0.02 \%$ & 17.50 a-e & $18.24 \mathrm{a}-\mathrm{c}$ & $16.21 \mathrm{~b}-\mathrm{g}$ & $17.65 \mathrm{~A}$ \\
\hline Tytanit $0.04 \%$ & $14.54 \mathrm{c}-\mathrm{j}$ & $15.82 \mathrm{~b}-\mathrm{h}$ & $12.92 \mathrm{f}-\mathrm{j}$ & $14.98 \mathrm{~B}$ \\
\hline Chryzotop Green (0.25\% IBA) & $19.97 \mathrm{a}$ & $14.33 \mathrm{~d}-\mathrm{j}$ & $11.80 \mathrm{ij}$ & $16.58 \mathrm{AB}$ \\
\hline Rhizopon AA 020 XX (2.00\% IBA) & $18.46 \mathrm{ab}$ & $13.14 \mathrm{f}-\mathrm{j}$ & $11.55 \mathrm{j}$ & $15.75 \mathrm{~B}$ \\
\hline Mean & $17.93 \mathrm{~A}^{\prime \prime}$ & $14.9 \mathrm{~B}$ & $13.99 \mathrm{~B}$ & \\
\hline
\end{tabular}

Note: different letters indicate significant interactions between treatment and thickness of cuttings, according to Tukey's HSD test $(P \leq 0.05$; two-way ANOVA);

Note: mean values marked with the same capital letters in column or row do not differ significantly at $P \leq 0.05$ according to Tukey's HSD test

Table 10. The means of total leaf area of rooted root-cuttings of Rosa gallica 'Tuscany Superb'

\begin{tabular}{|c|c|c|c|c|}
\hline \multirow{2}{*}{ Treatment } & \multicolumn{3}{|c|}{ Total leaf area in $\mathrm{cm}^{2} /$ Thickness of root cuttings } & \multirow{2}{*}{ Mean } \\
\hline & Thick & Medium & Thin & \\
\hline Control & $94.94 \mathrm{fgh}$ & $74.07 \mathrm{j}-\mathrm{m}$ & $57.76 \mathrm{n}$ & $75.59 \mathrm{~B} "$ \\
\hline Root Juice $0.1 \%$ & $107.48 \mathrm{efg}$ & $63.79 \mathrm{lmn}$ & $67.78 \mathrm{k}-\mathrm{n}$ & $79.68 \mathrm{~B}$ \\
\hline Root Juice $0.2 \%$ & $110.25 \mathrm{c}-\mathrm{f}$ & 89.78 hi & $74.11 \mathrm{j}-\mathrm{m}$ & $91.38 \mathrm{AB}$ \\
\hline Root Juice $0.4 \%$ & $122.78 \mathrm{a}-\mathrm{d}$ & $95.29 \mathrm{fgh}$ & $94.95 \mathrm{gh}$ & $104.34 \mathrm{AB}$ \\
\hline Tytanit $0.01 \%$ & 118.99 a-e & $109.39 \mathrm{~d}-\mathrm{g}$ & $79.28 \mathrm{ijk}$ & $102.55 \mathrm{AB}$ \\
\hline Tytanit $0.02 \%$ & $124.92 \mathrm{abc}$ & $117.78 \mathrm{~b}-\mathrm{e}$ & 89.45 hi & $110.72 \mathrm{~A}$ \\
\hline Tytanit $0.04 \%$ & $133.22 \mathrm{a}$ & $100.22 \mathrm{f}-\mathrm{h}$ & 85.21 hij & $106.22 \mathrm{~A}$ \\
\hline Chryzotop Green (0.25\% IBA) & $127.89 \mathrm{ab}$ & $89.28 \mathrm{hi}$ & $60.13 \mathrm{mn}$ & $92.43 \mathrm{AB}$ \\
\hline Rhizopon AA 020 XX (2.00\% IBA) & 118.83 a-e & $78.12 \mathrm{jkll}$ & $68.79 \mathrm{k}-\mathrm{n}$ & $88.58 \mathrm{AB}$ \\
\hline Mean & $117.70 \mathrm{~A}^{* *}$ & $90.86 \mathrm{~B}$ & $75.27 \mathrm{~B}$ & \\
\hline
\end{tabular}

Note: different letters indicate significant interactions between treatment and thickness of cuttings, according to Tukey's HSD test $(P \leq 0.05$; two-way ANOVA);

"Note: mean values marked with the same capital letters in column or row do not differ significantly at $P \leq 0.05$ according to Tukey's HSD test 


\section{Conclusions}

The results from the present study clearly demonstrate that Rosa gallica 'Tuscany Superb' can be propagated by root cuttings according to anatomical structure of their root cuttings and the enough high level of carbohydrates. The most useful root cuttings achieving the highest rooting percentage with the use of the preparations as root stimulators in the experiment are the medium cuttings. However, after analysing the experimental results it can be said that the commercial preparations used for the studied rose cultivars could be considered important for propagation purposes. The effective were IBA preparation, but also the eco-friendly preparations Root Juice ${ }^{\mathrm{TM}} 0.01 \%$ and Tytanit in a solution of $0.04 \%$. The influence of biostimulants, which contain biologically active components, are beneficial in the growth and the level of carbohydrates in roses, thus they could be suggested in Rosa root cuttings propagation.

\section{Conflicts of interest}

The authors declare that there are no conflicts of interest related to this article.

\section{Acknowledgements}

This research was possible thanks to activity in "National Plant Genetic Conservation Programme, Task 1.3. Collection, preservation of collections ex situ, cryopreservation and characterization, evaluation, documentation and sharing of genetic resources and information in the field of vegetable, fruit, ornamental and providing pollen and related wild species (2015-2020)".

\section{References}

BioBizz Worldwide BV (2017). Root Juice ${ }^{\mathrm{TM}}$. Retrieved 2017 February 12 from http://www.biobizz.com/products/\#root\%c2\%b7juice.

Bosela MJ, Ewers FW (1997). The mode of origin of root buds and root sprouts in the clonal tree Sassafras albidum (Lauraceae). American Journal of Botany 84(11):1466-1481.

Calvo P, Nelson L, Kloepper JW (2014). Agricultural uses of plant biostimulants. PlantSoil 383(1-2):3-41.

Denaxa N-K, Vemmos SN, Roussos PA (2012). The role of endogenous carbohydrates and seasonal variation in rooting ability of cuttings of an easy and a hard to root olive cultivars (Olea europaea L.). Scientia Horticulture 143:19-28.

Dumon JC, Ernst WHO (1988). Titanium in plants. Journal of Plant Physiology 133(2):203-209.

Ercişli S, Eşitken A, Anapali O, Şahin U (2005). Effects of substrate and IBAconcentration on adventitious root formation on hardwood cuttings of Rosa dumalis. Acta Horticulturae 751:149-152.

ErmelFF, Vosozo S, Charpentier JP, Jay-Allemand C, Catesson AM, Couée I (2000). Mechanism of primordium formation during adventitious development from walnut cotyledon explants. Planta 211(4):563-574.

Hartmann HT, Kester DE, Davies FT, Geneve RL (2011). Plant propagation: Principles and practices. 7 th Ed Pearson Education, Upper Saddle River, NJ,USA.
Hoşafçi H, Arslan N, Sarihan EO (2005). Propagation of dogrose (Rosa canina L) plants by softwood cuttings. Acta Horticulturae 690:139-142.

Husen A (2008). Stock-plant etiolation causes drifts in total soluble sugars and anthraquinones, and promotes adventitious root formation in teak (Tectona grandis L.) coppice shoots. Plant Growth Regulation 54:13-21.

Kazankaya A, Yörük E, Doğan A (2005). Effect of IBA on rooting of Rosa canina hardwood cuttings from Lake Van region, Turkey. Acta Horticulturae 690:153-158.

Kuzel S, Cigler P, Hruby P, Vydra M, Pavlikova JD, Tlustos P (2007). The effect of simultaneous magnesium application on the biological effects of titanium. Plant, Soil and Environment 53(1):16-23.

Ky-Dembele C, Tigabu M, Bayala J, Savadogo P, Boussim IJ, Odén C (2010). Clonal propagation of Detarium microcarpum from root cuttings. Silva Fennica 44(5):775-785.

Leskó K, Stefanovits-Bányai É, Pais I, Simon-Sarkadi L (2002). Effect of cadmium and titanium - ascorbate stress on biological active compounds in wheat seed lings. Journal of Plant Nutrition 25(11):2571-2581.

Lyu S, Wei X, Chen J, Wang C, Wang X, Pan D (2017). Titanium as a beneficial element forcrop production. Frontiers in Plant Sciences 8:597.

MahmoudEA (1964). Factors affecting the rooting of hardwood cuttings of $R$ multiflora. Master of Science Thesis. Department of Horticulture. The University of Arizona, USA.

Marcinek B, Hetman J (2008). The effect of foliage feeding on the structure of yield, dry weight content and macroelements in the corms of Sparaxis tricolor Ker-Gawl. Acta Scientiarum Polonorum, Hortorum Cultus 7(4):89-99.

Monder MJ, Niedzielski M, Woliński K (2014). Effect of rooting preparations on protein, chlorophyll and carotenoid content in leaves of Rosa gallica 'Duchesse d'Angoulême' cuttings. Dendrobiology 72:29-40.

Monder MJ (2016). Study on propagation of shrub and pillar roses by hardwood cuttings with auxins preparations. Acta Scientiarum Polonorum Hortorum Cultus 11(2):93-103.

Monder MJ, Pacholczak A (2018). Preparations of plant origin enhance carbohydrate content in plant tissues of rooted cuttings of rambler roses Rosa beggeriana 'Polstjärnan' and Rosa helenae 'Semiplena'. Acta AgriculturaeScandinavica, Section B-Soil \& PlantScience 68(3):189-198. Nasri F, Fadakar A, Saba MK, Yousefi B (2015). Study of indole butyric acid (IBA) effects on cutting rooting improving some of wild genotypes of damask roses (Rosa damascena Mill.). Journal of Agricultural Sciences 60(3):263-275.

Perala DA (1978). Aspen suckers production and growth from outplanted root cuttings. North Central Experiment Forest Station Research Note, Forest Service USDA: NC-241,pp 14.

Schier GA, Zasada JC (1973). Role of the carbohydrate reserves in the development of root suckers in Populus tremuloides. Canadian Journal ofForest Research 3(2):243-250.

Snedden J, Landhäusser SM, Lieffers VJ, Charleson LR (2010). Propagating trembling aspen from root cuttings: impact of storage length and phenological period of root donor plants. New Forest 39(2):169-182.

Terpiński Z. (1984). Szkółkarstwo ozdobne. [The ornamental plants nursery]. Warsaw (PL): Państwowe Wydawnictwo Rolnicze iLeśne.

Toczko M, Grzelińska A (2001). Materiały do ćwiczeń z biochemii. Warsaw. WydawnictwoSGGW. 